\title{
THE SECOND STAGE OF STRESSED-DEFORMED CONDITION OF REINFORCED CONCRETE STRUCTURES WHEN TURNING WITH BENDING (CASE 2)
}

\author{
Vladimir I. Kolchunov, Aleksey I. Demyanov, Nikolay V. Naumov \\ South-Western State University, Kursk, RUSSIA
}

\begin{abstract}
It is proposed a complex resistance computational model of reinforced concrete constructions in buildings and structures under the action torsion with bending. It consists of from the block near the support (formed by a spatial crack and a compressed concrete zone closed by it - a spatial section k) and a second block, which is formed by a vertical cross section I-I passing perpendicularly to the longitudinal axis of the reinforced concrete element along the edge of the compressed zone, which closes the spatial spiral-shaped crack. The case when the greatest influence on the stress-strain state of structures has the effect of torque is considered (case 2). In this case, as the calculated forces are taken into account in the spatial section: normal and tangential forces in the concrete of the compressed zone; components of axial and "dowel" efforts in the working reinforcement, intersected by a spiral spatial crack. The resolving equations are constructed that form a closed system and the Lagrange function is unified. Using the partial derivatives of the constructed function with respect to all the variables entering into it and equating them to zero, an additional system of equations is constructed. The dependence is obtained after the corresponding algebraic transformations, that allows us to search for the projection of a dangerous spatial crack.
\end{abstract}

Keywords: calculation methodics, torsion, stress-strain state, reinforced concrete constructions, spatial crack, Lagrange function

\section{ВТОРАЯ СТАДИЯ НАПРЯЖЕННО-ДЕФОРМИРОВАННОГО СОСТОЯНИЯ ЖЕЛЕЗОБЕТОННЫХ КОНСТРУКЦИЙ ПРИ КРУЧЕНИИ С ИЗГИБОМ (СЛУЧАЙ 2)}

\author{
Вл.И. Колчунов, А.И. Демьянов, Н.В. Наумов \\ Юго-Западный Государственный Университет, г. Курск, РОССИЯ
}

\begin{abstract}
Аннотация. Предложена расчетная модель сложного сопротивления железобетонных конструкций в зданиях и сооружениях при кручении с изгибом, состоящая из приопорного блока (образованного пространственной трещиной и замыкаемой на нее сжатой зоной бетона, - пространственное сечение $\mathrm{k}$ ) и второго блока, образуемого вертикальным сечением I-I, проходящим перпендикулярно к продольной оси железобетонного элемента по краю сжатой зоны, замыкающей пространственную спиралеобразную трещину. Рассмотрен случай когда наибольшее влияние на напряженно-деформирванное состояние конструкций оказывает действие крутящего момента (случай 2). При этом в качестве расчетных усилий в пространственном сечении учитываются: нормальные и касательные усилия в бетоне сжатой зоны; составляющие осевых и нагельных усилий в рабочей арматуре, пересекаемой спиралеобразной пространственной трещиной. Составлены разрешающие уравнения, образующие замкнутую систему и записана функция Лагранжа их объединяющая. Используя частные производные построенной функции по всем входящим в нее переменным и приравнивая их нулю, составлена дополнительная система уравнений, из которой после соответствующих алгебраические преобразований, получена зависимость, позволяющая отыскивать проекцию опасной пространственной трещины.
\end{abstract}

Ключевые слова: методика расчета, кручение, напряженно-деформированное состояние, железобетонные конструкции, пространственная трещина, функция Лагранжа 


\section{INTRODUCTION}

Building computational models of complex resistance - torsion with a bend is becoming increasingly relevant $[1,2]$, firstly, because there are relatively few such studies [3-9], and secondly, because the urgent need to take into account the spatial work of the majority of original reinforced concrete structures and buildingss that significantly change the architectural appearance of modern cities [10-12]; thirdly, it becomes a generally accepted postulate that there is nothing more practical than a good theory for calculation of reinforced concrete structures [13-23].

That is why the purpose of these studies is to develop a computational model of the resistance of reinforced concrete structures under the action of torsion with bending for a cross section of any shape that most fully reflect the features of their actual work [2, 12, 17].

For the calculated forces, the resolving equilibrium and strain equations are compiled. The projection of a dangerous spatial crack is determined as a function of many variables using Lagrange multipliers $[13,15]$.

\section{METHOD}

While solving a direct engineering problem with external forces, their ratio is always given $(\mathrm{Q}$ : M: T). Thus, having determined one of them, for example, the support reaction $\mathrm{R}_{\text {sup }}$, the other effects, for example, $M$ and $T$, can be easily found.

From the balance conditions in cross-section I-I and in the spatial cross-section can be sought the following design parameters (Figures 1, 2): the limiting support reaction $R_{\text {sup }}$; height of compressed zone $x$ in section $I-I$; stresses in the longitudinal reinforcement $\sigma_{s}$ at the place of its intersection with a spatial crack; the height of the compressed zone of concrete $x_{b}$ in a vertical plane passing through the end of the front of a spatial crack; running force in the transverse reinforcement located at the lateral faces of the spatial section $q_{s w, Q}$, caused by the transverse force; running force in the transverse reinforcement located at the lateral faces of the spatial section $q_{s w, T}$, caused by the torque; running force in the transverse reinforcement located at the lower edge of the spatial section $q_{s w, \sigma}$, caused by the torque.

Figure 1 shows: a) a support block (formed by a spatial section $\mathrm{k}$ ) and a block formed by a vertical section I-I, passing perpendicular to the longitudinal axis of the reinforced concrete element at the edge of the compressed zone closing the spatial spiral-shaped crack; b) - vertical section I - I (III - III), passing perpendicular to the longitudinal axis of the reinforced concrete element, stress plots in compressed concrete and tensioned reinforcement, as well as the distribution of torques in this section. Figure 2 shows spatial section $\mathrm{k}$ with projections of all the efforts that occur at the site of the section.

The shear stress $\tau_{Q}$ and the shear stress of torsion in compressed concrete $\tau_{T}$ are determined by projecting the $\sigma_{i}-\varepsilon_{i}$ diagram onto the $\tau-\gamma$ plane (taking into account the distribution in proportion to the $Q: T$ ratio) and onto the $I-I$ plane and projecting the components of the stresses of the $\mathrm{k}$ plane onto the plane perpendicular to the longitudinal axis of the reinforced concrete element.

To make the calculation equations, we will separate two blocks from the reinforced concrete element using the section method (Figures 1,2). The first block is separated by a cross section II, passing at the end of a spatial crack. This block is in equilibrium under the influence of external forces.

The second scheme (the first block - section 11) is realized with the resistance of reinforced concrete elements subject to the joint action of torques and transverse forces.

To make the calculation equations, we will separate two blocks from the reinforced concrete element using the section method (Figures 1,2). The first block is separated by a cross section II, passing at the end of a spatial crack. This block is in equilibrium under the action of ex- 
ternal forces from the support and internal forces arising at the section.

The proposed calculation model is based on the following prerequisites:

- the spatial crack on the lower face of the reinforced concrete element forms perpendicular to the direction of the main deformations of the elongation of the concrete, and the location of the end of the front of the spatial crack at the compressed edge of the reinforced concrete element coincides with the direction of the main deformations of the concrete shortening thus, the spatial crack has a spiral shape with three possible layouts of the compressed zone - Figure 2;

- the calculation scheme is taken as a design consisting of a support block (formed by a spatial crack and a vertical section passing through the end of the front of this crack in compressed concrete) and a second block formed by a vertical section perpendicular to the longitudinal axis of the reinforced concrete element along the edge of the spatial crack - Figures 1, 2;

- in the spatial section for making the calculation equations following forces are taken into account: normal and tangential forces in the concrete of the compressed zone; components of axial forces in the reinforcement located at the face opposite to that in which the compressed zone is located; components of axial forces in the transverse reinforcement located at the side faces of the reinforced concrete element;

- for medium fiber deformations of compressed concrete and tensiled reinforcement in section $I-I$, is fair hypothesis of their proportionality to the heights of the compressed and stretched section zones;

- the relationship between the strain intensity $\varepsilon_{i}$ and the stress intensity $\sigma_{i}$ of concrete is taken in the form of a diagram shown in Figures $3 \mathrm{a}, \mathrm{b}$ (for practical calculations, the curvilinear diagram of compressive stresses is replaced by a rectangular diagram above a spatial crack in cross-section $k$ - see Fig. 3 $\mathrm{c}, \mathrm{d}$, and in cross-section $I-I$ in site $x_{b}-$ rectangular, in site $x-x_{b}$ - triangular).

The curved section of the $\left\langle\sigma_{\mathrm{i}}-\varepsilon_{\mathrm{i}}\right\rangle$ diagram (Figure 3 a) is described by a square parabola:

$$
\sigma_{i}=\frac{R_{b}-E_{b} \cdot \varepsilon_{b r}}{\varepsilon_{b r}^{2}} \cdot \varepsilon_{i}^{2}+E_{b} \varepsilon_{i}
$$

and straightforward as a linear function:

$$
\sigma_{i}=R_{b}-\frac{R_{b}(1-\beta)}{\varepsilon_{b u}-\varepsilon_{b r}} \cdot\left(\varepsilon_{i}-\varepsilon_{b r}\right)
$$

The parameters $\mathrm{R}_{\mathrm{crc}, 0}$ and $\mathrm{R}_{\mathrm{crc}, \mathrm{v}}$ can be calculated by the formulas given in the reference book [19].

Then $\varepsilon_{\mathrm{crc}, 0}, \varepsilon_{\mathrm{crc}, \mathrm{v}}$. can be determined from the diagrams (Figure 3a). For example,

$$
\varepsilon_{c r c, v}=\frac{E_{b} \cdot \varepsilon_{b r}^{2}}{E_{b} \cdot \varepsilon_{b r}-R_{b}}+\sqrt{\frac{E_{b}^{2} \cdot \varepsilon_{b r}^{4}}{\left(E_{b} \cdot \varepsilon_{b r}-R_{b}\right)^{2}}+R_{c r c, v}}
$$

The value of $\mu(\lambda)$ at point $H$ corresponds to its value at the point (at these points the stresses in concrete are the same):

$$
\begin{gathered}
\mu(\lambda)=0,2+\frac{0,3 \cdot\left(\varepsilon_{\beta}-\varepsilon_{c r c, 0}\right)}{\varepsilon_{c r c, v}-\varepsilon_{c r c, 0}}, \\
\varepsilon_{\beta}=\frac{E_{b} \cdot \varepsilon_{b r}^{2}}{E_{b} \cdot \varepsilon_{b r}-R_{b}}+\sqrt{\frac{E_{b}^{2} \cdot \varepsilon_{b r}^{4}}{\left(E_{b} \cdot \varepsilon_{b r}-R_{b}\right)^{2}}} .
\end{gathered}
$$

The formation of cracks in concrete and its destruction is described by various theories of strength, since the cause of cracking is always the main deformation of the separation, and the cause of the destruction can also be shear deformation at the octahedral sites. For the accepted version of the deformation theory of concrete ductility [2], we will give preference to deformation criteria of strength, because for concrete located in structural elements, experimental verification of only deformations is possible. The 
requirements are also presented for the possibility of a direct transition of the stress - strain dependences to the strength condition.

The equations above contain the parameters $R_{q}$, $\varepsilon_{q, R}, \varepsilon_{q, u}, R_{b, z}, \varepsilon_{b, z}$, whose values are determined by projecting the diagram $\left\langle\sigma_{\mathrm{i}}-\varepsilon_{\mathrm{I}}\right\rangle$ on the corresponding planes, for example, $\left\langle\tau_{\mathrm{q}}-\varepsilon_{\mathrm{q}}\right\rangle$. Projection is carried out using the obtained formulas and formulas of mechanics of a solid deformable body for continuous sections of concrete [2]. When preparing equilibrium equations, it is also necessary to take into account the angle $\alpha$ associated with the projection of a dangerous spatial crack $c$ and the angle $\beta$ that determines the direction of the main deformations of concrete shortening in the vertical section $k$.

To make the calculation equations, we will separate two blocks from the reinforced concrete element using the section method (Fig. 1,2). The first block is separated by a cross section $I-I$, passing at the end of a spatial crack. This block is in equilibrium under the action of external forces applied to the block from the support side and internal forces arising at the section.

From the equation of equilibrium of moments of internal and external forces in section $I-I$ with respect to the $y$ axis, with respect to a point $O_{1}$ passing through the point of application of the resultant force in the tensiled reinforcement $\left(\sum M_{\mathrm{O}, \mathrm{I}}=0\right)$ :

$$
\begin{gathered}
\sigma_{b, x, \mathrm{I}} \cdot \omega_{b, \mathrm{I}} A_{b, \mathrm{I}}\left[b-\varphi_{y} \cdot x\right] \cdot \eta_{\mathrm{ver}, \mathrm{s}, \mathrm{I}} \cdot h \\
+\eta_{\mathrm{ver}, \mathrm{s}, \mathrm{I}} \cdot h \cdot R_{\mathrm{sc}, \mathrm{I}, \mathrm{rig}} \sum \cdot \omega_{r i g} \cdot A_{s c, r i g}+ \\
-\left(0,5 \mathrm{~h}-a_{s}^{\prime}+\eta_{\mathrm{s}, \mathrm{s}, \mathrm{I}} \cdot h\right) \cdot R_{\mathrm{s}, \mathrm{I}, \mathrm{up}} \cdot \sum \omega_{u p} \cdot A_{s, u p}+ \\
+\left(0,5 \mathrm{~h}-a_{s}^{\prime}+\eta_{\mathrm{s}, \mathrm{s}, \mathrm{I}} \cdot h\right) \cdot R_{\mathrm{sc}, \mathrm{I}, \mathrm{up}} \sum \cdot \omega_{u p} \cdot A_{s c, u p}+ \\
+\left(0,5 \mathrm{~h}-a_{s}-\eta_{\mathrm{s}, \mathrm{s}, \mathrm{I}} \cdot h\right) \cdot R_{\mathrm{s}, \mathrm{I}, \mathrm{d}} \cdot \sum \omega_{d} \cdot A_{s, d} \\
-\left(0,5 \mathrm{~h}-a_{s}-\eta_{\mathrm{s}, \mathrm{s}, \mathrm{I}} \cdot h\right) \cdot R_{\mathrm{sc}, \mathrm{I}, \mathrm{d}} \sum \cdot \omega_{d} \cdot A_{s c, d}- \\
-\mathrm{K}_{\mathrm{M}} K_{p r, M} \cdot R_{\mathrm{sup}}-R_{\mathrm{sup}} a_{\mathrm{m}, \mathrm{S}}=0 .
\end{gathered}
$$

Here $\mathrm{K}_{\mathrm{M}}$ - is a numerical coefficient that takes into account the static loading scheme from the position of additional bending moments along the length of the bar; $\mathrm{K}_{\mathrm{pr}, \mathrm{M}}$ - coefficient, ratio (it is known, is set) between $R_{\text {sup }}$ and $M ; a_{\mathrm{m}, \mathrm{S}}$ - the horizontal distance from the support in the direction of the $y$ axis to the center of gravity of the working longitudinal reinforcement in section $I-I$ (point $O_{1}$ ); $R_{\text {sup }}$ - the support reaction in the first block (Figure 1).

The unknown is found from this equation $\sigma_{b, x, \mathrm{I}}$. From the equilibrium equation of the projections of all the forces acting in section $I-I$ on the $x$ axis, the height of the concrete compressed zone $\mathrm{x}$ in this section is determined $\left(\sum \mathrm{X}=0\right)$ :

$$
\begin{gathered}
\sigma_{b, x, \mathrm{I}} \cdot \omega_{b, \mathrm{I}} A_{b, \mathrm{I}}\left[b-\varphi_{y} \cdot x\right]-R_{\mathrm{s}, \mathrm{I}, \mathrm{up}} \cdot \sum \omega_{u p} \cdot A_{s, u p} \\
+R_{\mathrm{sc}, \mathrm{I}, \mathrm{lup}} \sum \cdot \omega_{u p} \cdot A_{s c, u p}-\sigma_{\mathrm{s}, \mathrm{I}, \mathrm{d}} \cdot \sum \omega_{d} \cdot A_{s, d} \\
+R_{\mathrm{sc}, \mathrm{I}, \mathrm{d}} \sum \cdot \omega_{d} \cdot A_{s c, d}=0
\end{gathered}
$$

From the equilibrium equation of the projections of internal and external forces acting in the section $I-I$ on the $0 Z$ axis $\left(\sum Z=0\right)$ (the loading forces in the working reinforcement in the middle section are zero), we obtain:

$$
-\tau_{p l, x} \cdot x \cdot h_{0}-\gamma_{Q, t} \tau_{p l, x} \cdot \psi_{R, Q} \cdot h_{0} \cdot(b-x)+K_{M} \cdot R_{\text {sup }}=0
$$

Here $\tau_{p l, x}$ is the shear stress determined in the second stage of stress-strain state.

From it is determined

$$
\gamma_{Q, t}=\frac{K_{M} \cdot R_{\mathrm{sup}}-\tau_{p l, x} \cdot x \cdot(b-x)}{\tau_{p l, x} \cdot \psi_{R, Q} \cdot h_{0} \cdot(b-x)}
$$

In this case, the transverse force perceived by the concrete of the compressed zone will be equal to:

$$
\mathrm{Q}_{\mathrm{I}, \mathrm{b}}=\tau_{p l, x} \cdot x \cdot h_{0},
$$

Ehe transverse force perceived by the concrete of the stretched zone will be equal to: 
a)

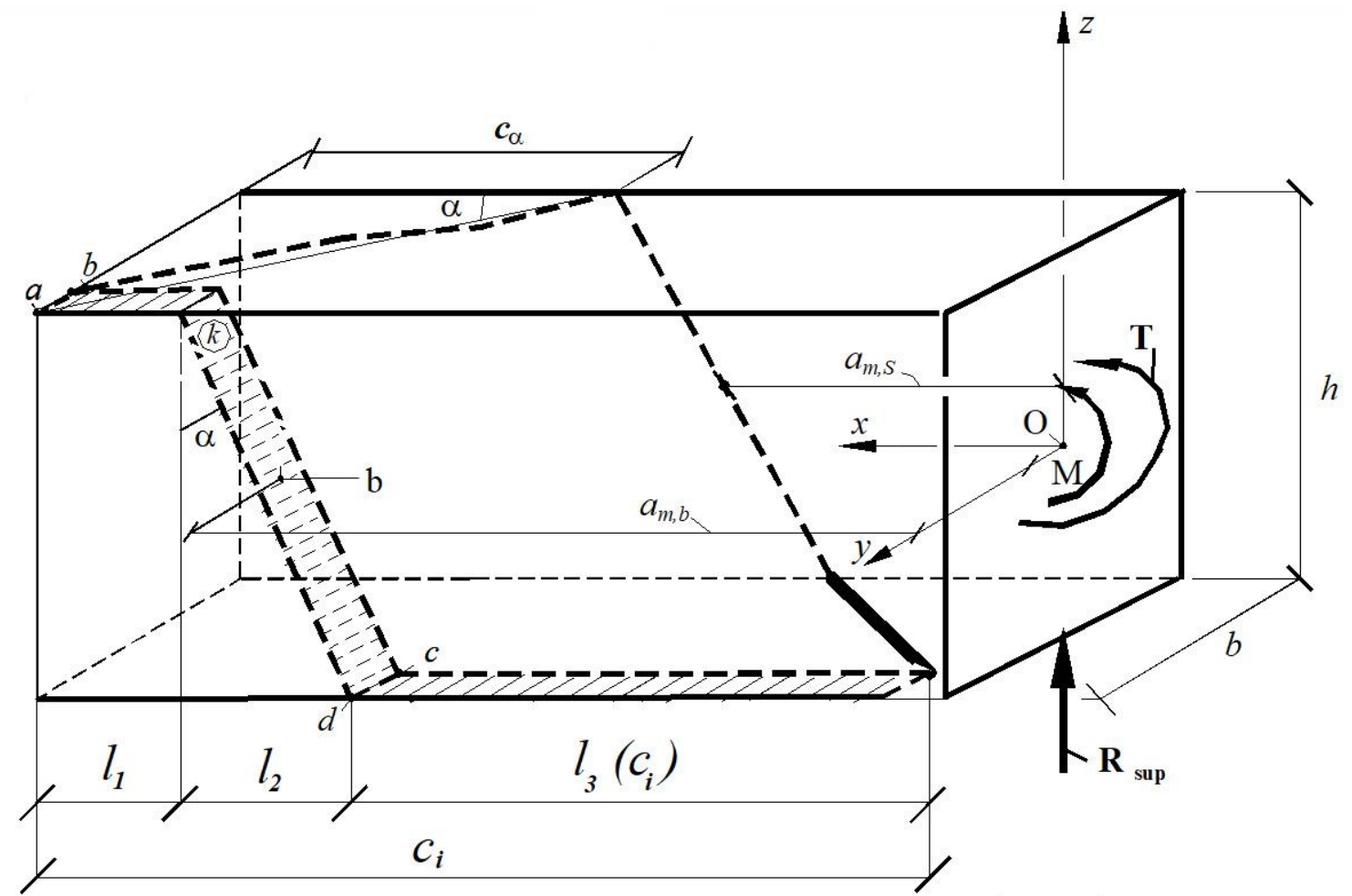

b)

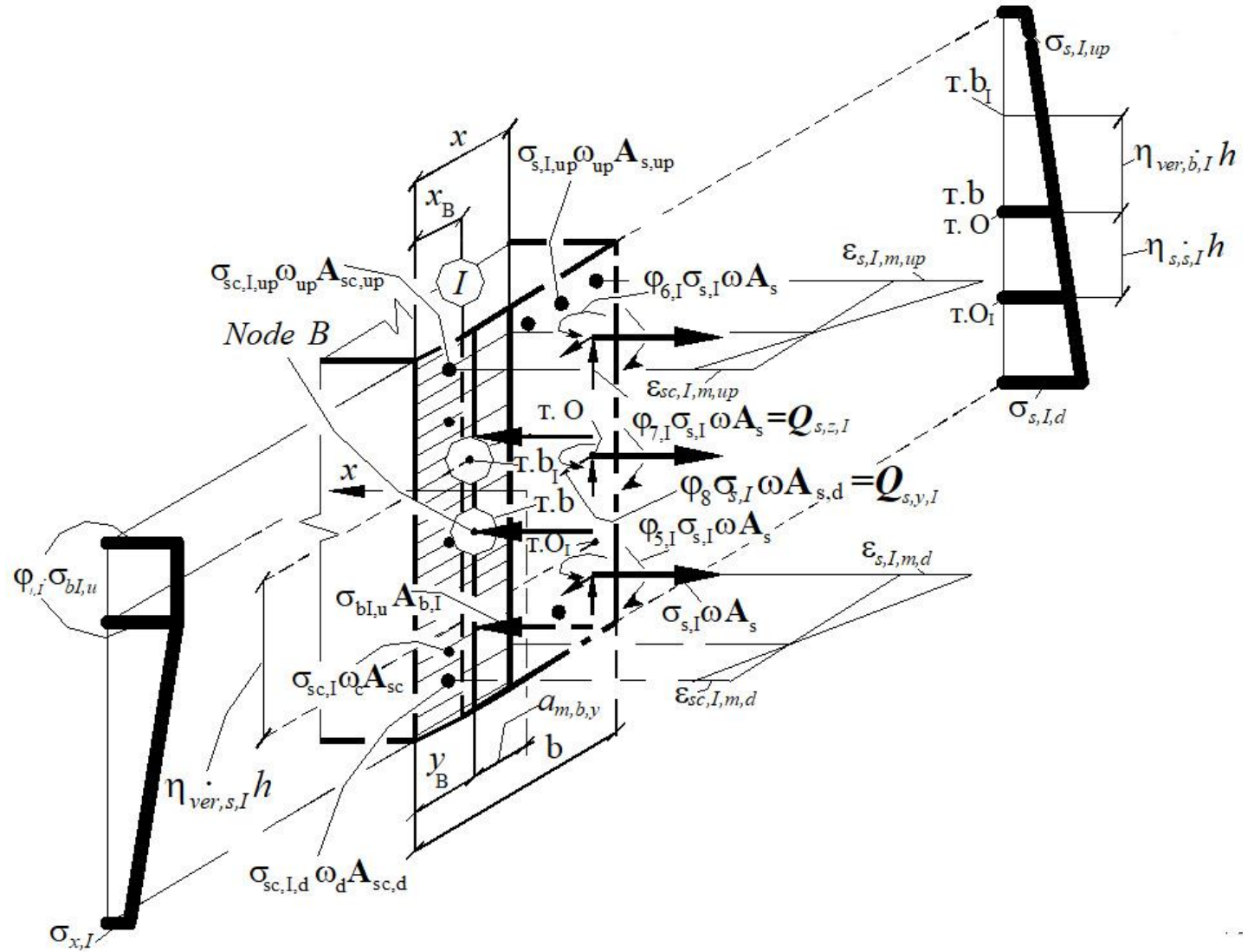

Figure 1. The calculation scheme of the resistance of the reinforced concrete structure under the combined action of bending moment, torque and shear force (case 2): () -compressed zone of spatial section; (I) - compressed section zone I-I (III - III). 


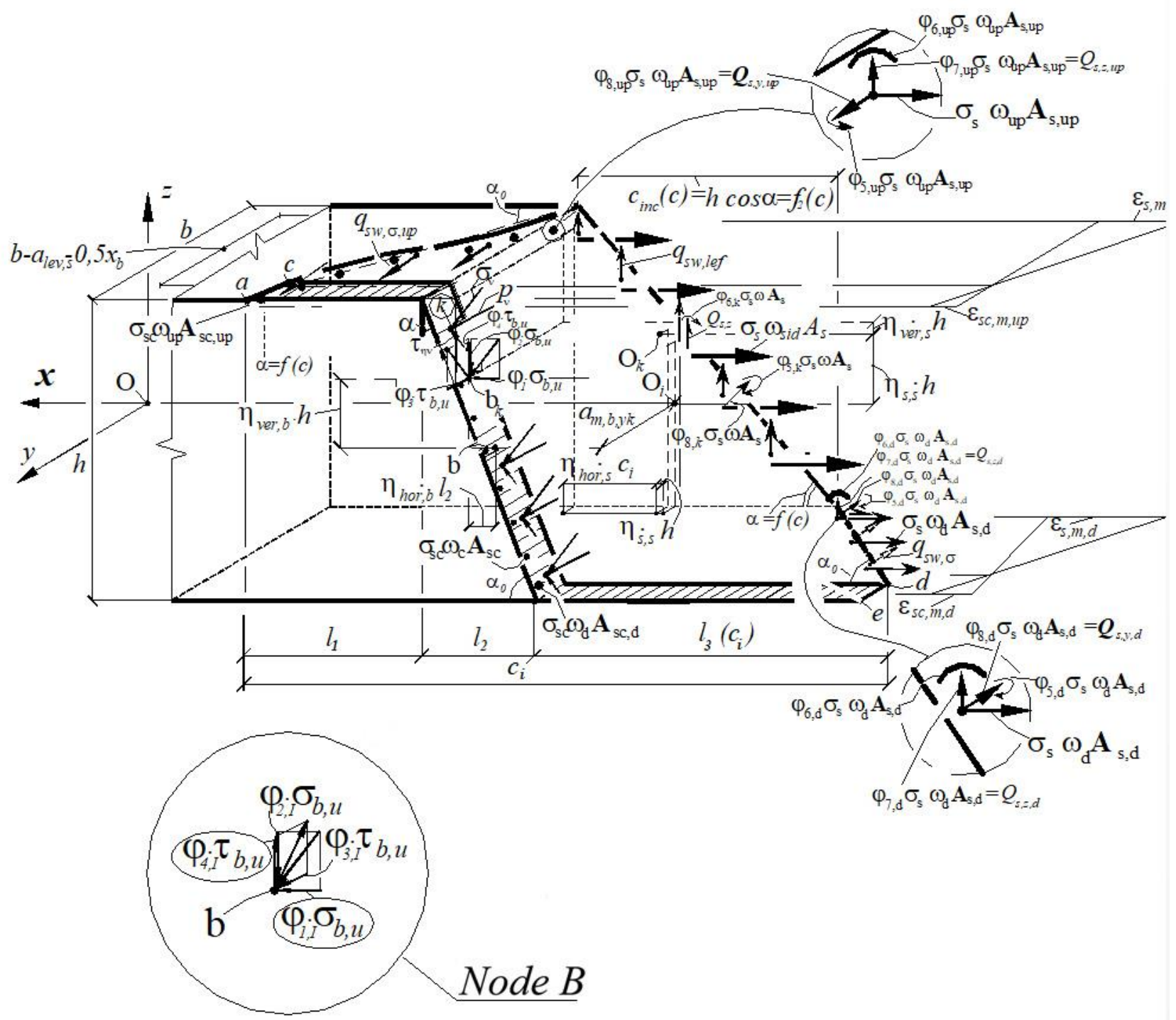

Figure 2. The calculation scheme of the spatial section $k$ :

(R) - compressed zone of spatial section.

$$
\mathrm{Q}_{I, t}=\gamma_{Q, t} \tau_{p l, x} \cdot \psi_{R, Q} \cdot h_{0} \cdot(b-x)
$$

As unknown, the system of differential equations is set $\gamma_{Q, t}$.

On the other hand:

$$
Q_{I, t}=Q-Q_{I, b}
$$

The last equation can be used to determine a parameter $\psi_{R, Q}$ that takes into account the presence of adjacent spatial cracks in the stressstrain state of the extended zone of the middle section $I-I$ :

$$
\psi_{R, Q}=\frac{Q-Q_{I, b}}{\gamma_{Q, t} \tau_{p l, x} \cdot h_{0} \cdot(b-x)} .
$$

The compilation of the following equations requires some explanation. The upper, lower and lateral longitudinal reinforcement (in the presence of multi-tiered), in Fig. 1 are not shown in order to avoid cumbersome images. Under equilibrium conditions, stresses arising in the marked reinforcement are taken into account. The only exception is the equation of equilibri- 
um of the moments of internal and external forces acting in section $I-I$ with respect to the $x$ axis perpendicular to this section and passing through the point of application of the resultant

a)

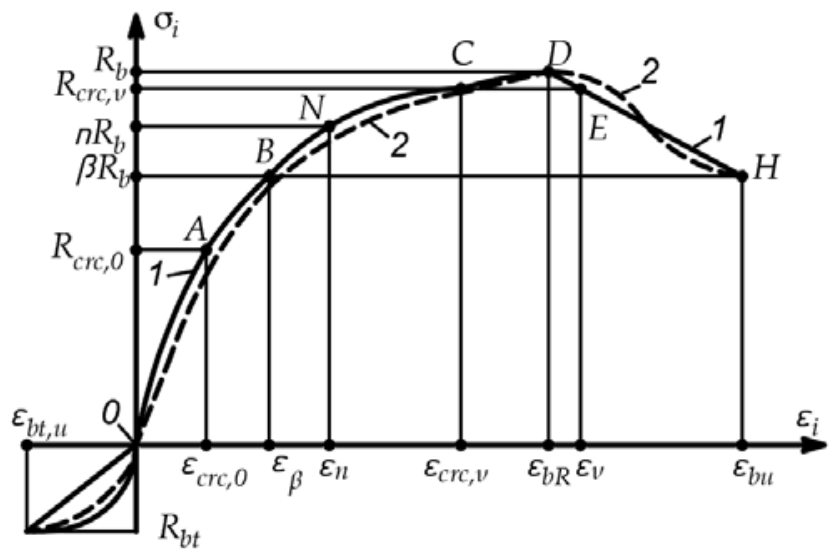

c)

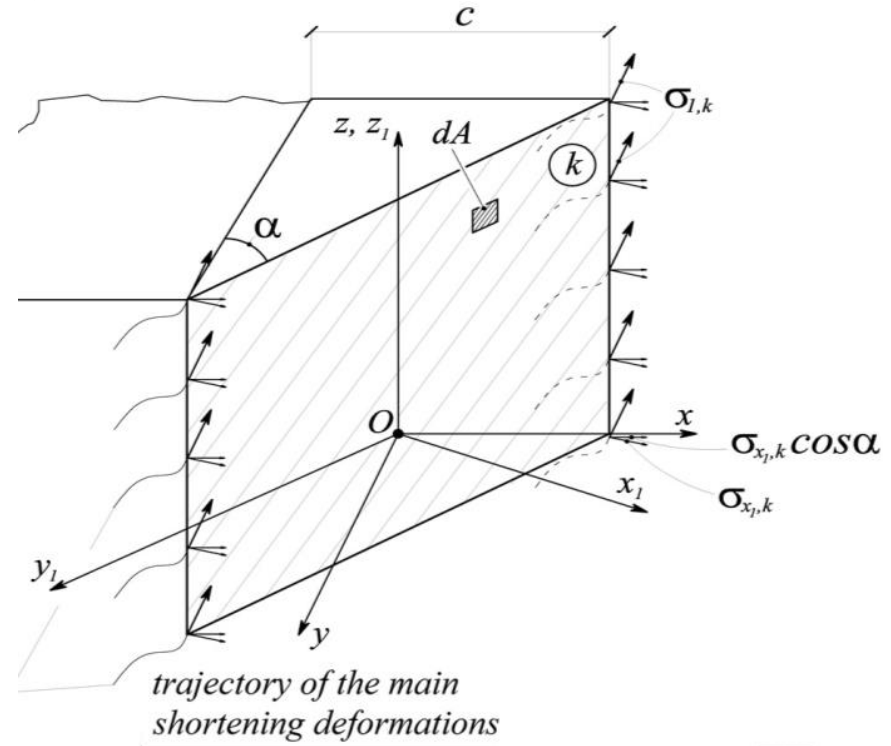

forces in the compressed zone $\left(T_{b, F}=0\right)$ (the loading forces in the reinforcement in the middle section $I-I$ are taken equal to zero).

b)

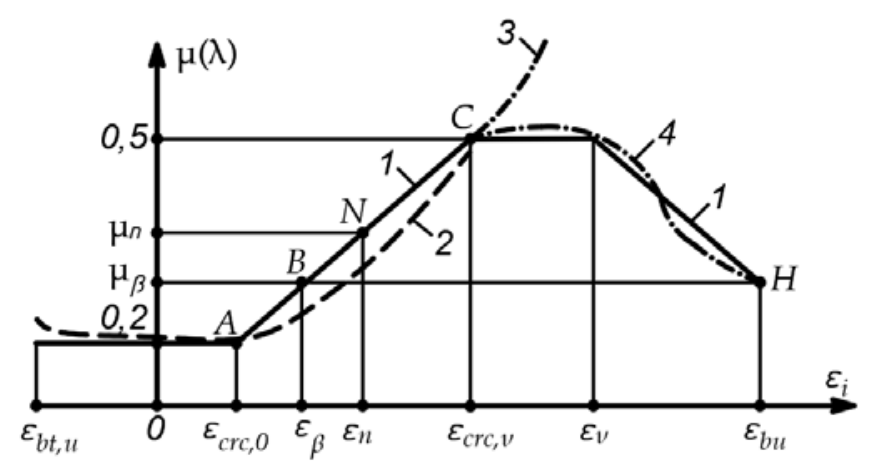

d)

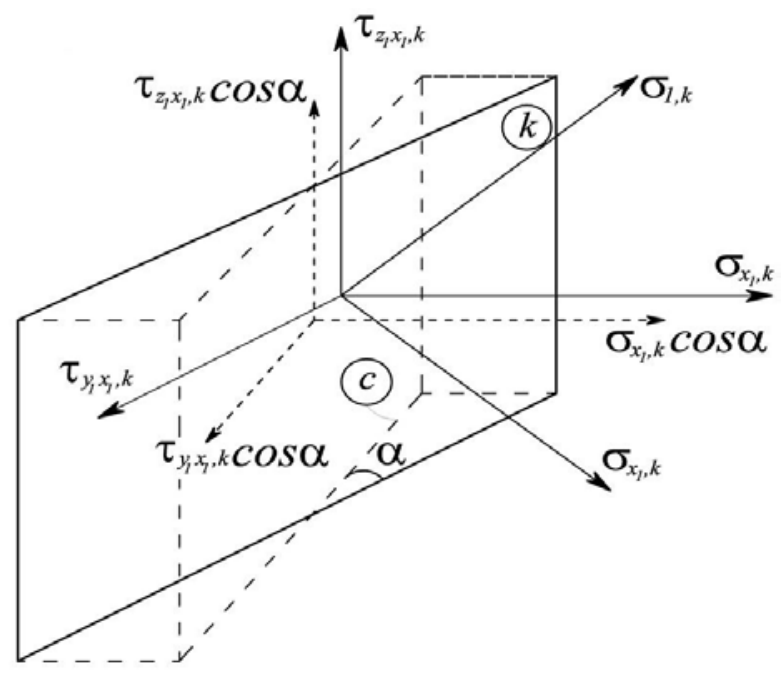

Figure 3. Connection diagrams "stresses - strain" (a), "Transverse strain coefficient" (b)

for concrete: 1 - calculated; 2 - built on experimental data; 3 - the same taking into account the main cracks between the pillars; 4 - the same with the measurement of deformations only within the pillars; stresses in the vertical section and the spatial cross-section diagram $k$ passing through the end of the front of the spatial crack (c), components of the stresses at the elementary site of the cross-section $k$ applied to the block from the support side, and internal forces arising at the cross-section location (d).

In the spatial section $k$ for block 2, cut off by a complex section passing along a spiral-shaped spatial crack and along the broken section of the compressed zone, all the reinforcement $[12,19]$ falling into this section are taken into account
(Figure 2). Moreover, in the compressed upper longitudinal reinforcement, cut off in sections I - I and III - III, the impact effect is not taken into account, and in the rest of the longitudinal and transverse reinforcement, the components 
of the impact effects are taken into account they are determined using a special second-level model $[1,2,13,15]$

The need to use a complex broken section of the compressed concrete zone is due to the fact that its destruction occurs (according to the experimental studies) in a certain volume, located not along the entire length between points $A$ and $B$ (Fig. 1,2), but only in a certain volume located in the middle part . Moreover, the destruction occurs in the middle part not along the $A B$ line, but at an angle close to $45^{\circ}$, located near the upper edge of the reinforced concrete structure, which predetermined the direction of the middle part of the broken section, where the ultimate stress-strain state is reached.

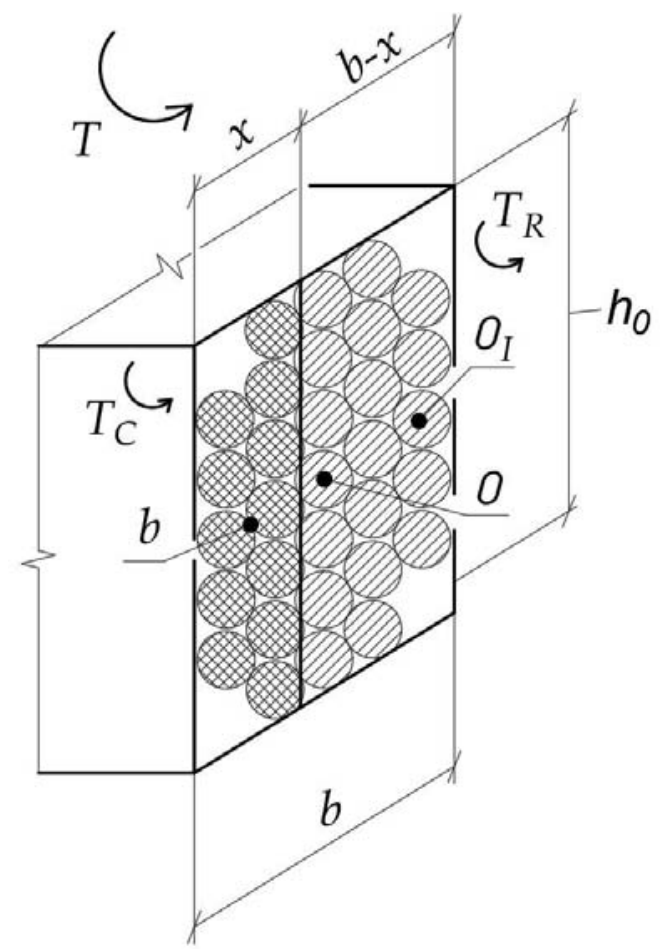

Figure 4. Approximation of a rectangular section I-I (III-III) using squares and circles inscribed in them and the distribution of torques in a compressed and extended zone in the middle section I - I (III-III).

In areas of the compressed zone located at the edges of the broken section, the stress-strain state varies from sections I - I and III - III to the middle zone according to linear dependences, respectively. At the same time, the height of the compressed zone decreases with increasing bending moment (Figure 2). Such a calculation scheme most closely matches the actual resistance, the parameters of which are experimentally confirmed.

The lateral surfaces of the broken section in compressed concrete coincide with the planes of the axis (or "smeared" plane) of the working longitudinal reinforcement. Thus, the angular reinforcement intersects the planes I - I, III III, respectively, at the end sections of a complex broken section (Figure 5).

The distribution of torques in the compressed and extended zones in the middle section $\mathrm{I}-\mathrm{I}$ is shown in Figure 4. When assessing the resistance of reinforced concrete structures of rectangular and complex cross sections (consisting of a set of rectangles), the authors use the technique, which is based on the fact that the rectangular section can be divided into a series of squares, which can be subsequently replaced by the circles inscribed in them (Figure 4).

The equation for determining the tangential torsional stresses $\tau_{\text {sum,A }}$ at the corresponding point of the cross section located at a distance from the support is written in a cylindrical and Cartesian coordinate system in accordance with Figure 4:

$$
\begin{aligned}
& \tau_{\text {sum }, \mathrm{A}}=\tau_{\mathrm{t}, \mathrm{j}, \mathrm{A}, \mathrm{cond}}+\tau_{\mathrm{t}, \mathrm{i}, \mathrm{A}, \mathrm{cond}}+\tau_{l o c}+\tau_{\text {conc }} \pm \tau_{\text {conc }, \text { loc }}= \\
& =\frac{M_{t}}{I_{t} \cdot \alpha} \cdot r_{j, A}+\frac{M_{t, i}}{I_{t, i} \cdot \alpha} \cdot r_{i, A}+\tau_{l o c}+\tau_{\text {conc }} \pm \tau_{\text {conc }, l o c}= \\
& =\frac{M_{t}}{I_{t} \cdot \alpha} \cdot \sqrt{y_{j, A}^{2}+z_{j, A}^{2}}+\frac{M_{t, i}}{I_{t, i} \cdot \alpha} \cdot \sqrt{y_{i, A}^{2}+z_{i, A}^{2}}+ \\
& +\tau_{l o c}+\tau_{c o n c} \pm \tau_{c o n c, l o c} \leq \tau_{t, u},
\end{aligned}
$$

Here $\tau_{\mathrm{t}, \mathrm{j}, \mathrm{A}, \text { cond }}$ and $\tau_{\mathrm{t}, \mathrm{i}, \mathrm{A}, \text { cond }}$ are the tangential stresses at an arbitrary point A of the large circle described around an arbitrary cross section after "condensation" of the static-geometric characteristics of the section "dissolved" along this circle and the tangential stresses at an arbitrary point A of the small square-circle after "conden- 
sation", respectively; $r_{j, A}, y_{j, A}, z_{j, A}$ - the distances from the center of the large circle described around the cross-section of the rod to an arbitrary point A located in the small $\mathrm{j}$-th circle, in which the values of the tangential torsional stresses $\tau_{t}$ and its coordinates are determined in the common coordinate system YOZ, respectively; $M_{t}$ - the torque acting in the cross section of the rod; $I_{t}$ - the polar moment of inertia of the cross section of the rod approximated by small squares - circles; $\tau_{\text {conc }}, \tau_{\text {conc,loc }}$ - shear stresses due to the force, geometric and interenvironment concentration of deformations, as well as components caused by local concentration; $r_{i, A}, y_{i, A}, z_{i, A}$ - the distances from the center of the small i-th circle to an arbitrary point A located in the small i-th circle, in which the tangential torsional stresses $\tau_{t}$ are determined and its coordinates in the local coordinate system $\mathrm{Y}_{\mathrm{i}} \mathrm{O}_{\mathrm{i}} \mathrm{Z}_{\mathrm{i}}$, respectively; $M_{t, i}$ - torque per ith small circle into which the cross section of the rod is divided; $I_{t, i}$ - the polar moment of inertia of the i-th small circle into which the cross section of the rod can be divided (consists of its own polar moment of inertia and an additional, equal to $\left.r_{j}^{2} \cdot A_{i}\right) ; \tau_{t, u}-$ limit values of tangential torsional stresses.

The torsion moment of inertia in the general case of a complex cross section is equal to the sum of the moment of inertia of the squares into which the section is divided, followed by approximation by circles inscribed in these squares (in this case, one of the superimposed parts of the intersecting sections when summing is entered with a «minus» sign, and angular sections, in view of their insignificant effect on the values of tangential stresses, are not taken into account):

$$
I_{t}=I_{t, 1}+I_{t, 2}+\ldots+I_{t, j}=\sum I_{t, j}
$$

The torsion moments falling on the inscribed circles are respectively determined:

$$
\begin{array}{r}
M_{t, 1}=M_{t} \cdot \frac{A_{t, 1}}{A_{t}} ; \quad M_{t, 2}= \\
M_{t} \cdot \frac{A_{t, 2}}{A_{t}} \\
\quad \ldots M_{t, j}=M_{t} \cdot \frac{A_{t, j}}{A_{t}}
\end{array}
$$

Here $A_{t, i}$ - the area of the small circle inscribed in the corresponding square; $A_{t}$ - area of rectangular cross section.

It is important to note that all geometric characteristics are considered relative to the geometric center of a complex section.

In relation to the average section $I-I$, under conditions of complex resistance - torsion with bending (Figure 5), it is advisable to take into account the fact that a significant part of this section is subject to tension. It is known [1, 2, 15] that in a stretched concrete there are a number of adjacent spatial cracks that affect the stress-strain state of the middle section $I-I$. We will take into account this effect of adjacent cracks using the parameter $\psi_{R, T}$ :

If the torque changes along the longitudinal axis of the reinforced concrete structure, an additional dependence is introduced, which is a proportional relationship between the torques in section $k$ and section $I-I$.

$$
\begin{gathered}
\frac{\mathrm{K}_{\mathrm{T}} \cdot \mathrm{K}_{\mathrm{pr}, \mathrm{T}} \cdot M_{t, I}}{M_{t, k}}=\frac{a}{c_{i}-0,5 b \cdot \sin \alpha_{0}}, \\
M_{t, I}=\frac{a \cdot M_{t, k}}{\mathrm{~K}_{\mathrm{T}} \cdot \mathrm{K}_{\mathrm{pr}, \mathrm{T}} \cdot\left(c_{i}-0,5 b \cdot \sin \alpha_{0}\right)} .
\end{gathered}
$$

Here $\mathrm{K}_{T}$ - a numerical coefficient that takes into account the static loading scheme from the position of additional torques along the length of the rod; $\mathrm{K}_{\mathrm{pr}, \mathrm{T}}$ - coefficient of ratio (it is known, is set) between $R_{\text {sup }}$ and $T$. Here $a-$ the horizontal distance from the center of the support to section $I-I$.

Knowing $\tau_{\text {sum,A }}$ from equation (14), you can find the torque per $\mathrm{j}$-th circle of the compressed zone in section $I-I$ according to the formula: 
Second Stage of Stressed-Deformed Condition of Reinforced Concrete Structures When Turning with Bending

$$
T_{c}=M_{t, c}=\frac{\tau_{s u m, A} \cdot I_{t, j}}{\sqrt{y^{2}+z^{2}}} .
$$

Performing the summation of all $M_{t, j}$ for all $\mathrm{j}$ th $m$ circles, located in the compressed zone of section $I-I$, we will have the total torque perceived by the compressed concrete zone:

$$
M_{t, c}=\sum_{j=1}^{m} M_{t, j}
$$

In turn, the torque perceived by the concrete of the stretched zone will be equal to:

$$
T_{R}=M_{t, R}=\frac{\tau_{\text {sum }, A} \cdot \psi_{R, T} \cdot I_{t, j}}{\sqrt{y^{2}+z^{2}}},
$$

Here $\psi_{R, T}-$ a parameter that takes into account the presence of adjacent spatial cracks in the stress-strain state due to torsion of the extended zone of the middle section $I-I$.

On the other hand, returning to the construction of general resolving equations (Figures 1,2), here we can use the equation of equilibrium of the moments of internal and external forces acting in section $I-I$ relative to the axis perpendicular to this section and passing through the point of application of the resultant forces in the compressed zone $\left(T_{b, I}=0\right)$ :

$$
M_{t, R}=M_{t}-M_{t, c}
$$

From this equation is determined parameter $\psi_{R, T}$, that takes into account the presence of adjacent spatial cracks in the stress-strain state due to torsion of the stretched zone of the middle section $I-I$ :

$$
\psi_{R, T}=\frac{\left(M_{t}-M_{t, c}\right) \sqrt{y^{2}+z^{2}}}{\tau_{\text {sum }, A} \cdot I_{t, j}} .
$$

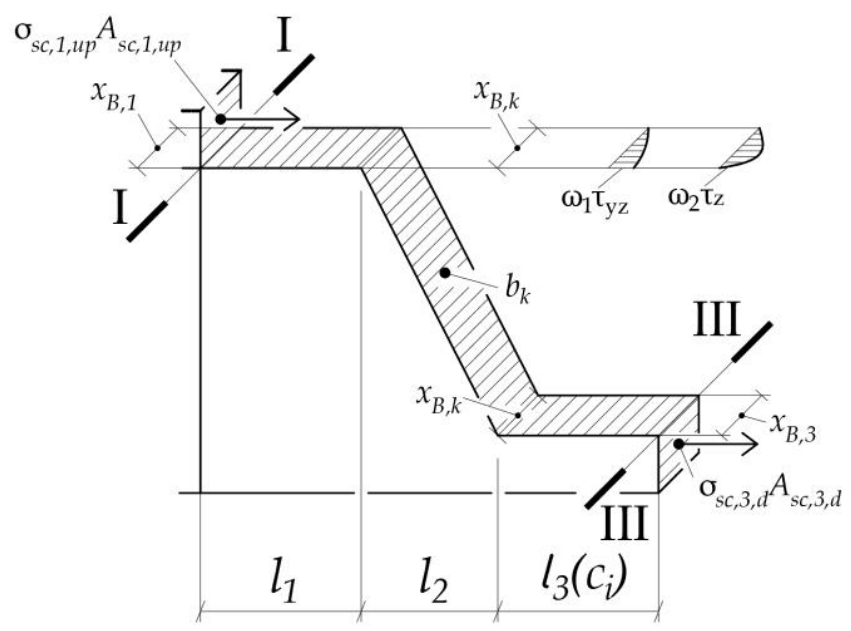

Figure 5. Approximation by a broken section of a compressed zone formed by a spiral-shaped spatial crack, as well as sections I-I and III-III.

From the hypothesis of proportionality of longitudinal strains, we find:

$$
\sigma_{s, I}=\frac{\sigma_{b, x, \mathrm{I}} \cdot E_{s}(\lambda)}{E_{b}(\lambda)} \cdot \frac{\left(\mathrm{b}-a_{s}-x\right)}{x}+\sigma_{0} \leq \mathrm{R}_{\mathrm{s}, \mathrm{I}} .
$$

Here $\sigma_{0}$ - prestresses in prestressed reinforcement at the moment of decreasing the prestressing value in concrete to zero when the structure is loaded by external forces, taking into account the prestressing losses in prestressed reinforcement corresponding to the considered stage of the construction. If condition (23) is not satisfied, then we set $\sigma_{s, I}$ equal to $R_{s, I}$.

The second support block is separated from the reinforced concrete element by a spatial section formed by a spiral crack and a vertical section passing through the compressed zone of concrete through the end of the front of the spatial crack.

The equilibrium of this block is ensured by the following conditions.

The sum of the moments of all internal and external forces acting in the vertical longitudinal plane with respect to the $y$ axis relative to the point of application of the resultant forces in the compressed zone is zero $\left(\sum M_{b, k}=0\right.$, block $\left.I I\right)$.).

$$
\left(0,5 h-\mathrm{a}_{s, d}+\eta_{v e r, b} h\right) \cdot \sum \mathrm{R}_{\mathrm{s}, \mathrm{d}} \cdot \omega_{\mathrm{s}, \mathrm{i}, \mathrm{d}} \cdot A_{s, i, d}
$$




$$
\begin{aligned}
& -\left(0,5 h-\mathrm{a}_{s, u p}-\eta_{\text {ver }, b} h\right) \cdot \sum \mathrm{R}_{\mathrm{s}, \mathrm{up}} \cdot \omega_{\mathrm{s}, \mathrm{i}, \mathrm{up}} \cdot A_{s, i, u p}+ \\
& +\varphi_{6, \text { up }} \cdot \sum R_{s, u p} \cdot \omega_{s, i, u p} \cdot A_{s, i, u p}+\varphi_{6, k} \cdot \sum R_{s} \cdot \omega_{s, i} \cdot A_{s, i} \\
& +\varphi_{6, \mathrm{~d}} \cdot \sum R_{s, d} \cdot \omega_{s, i, d} \cdot A_{s, i, d}+ \\
& +\varphi_{7 \text {, up }} \cdot\left[\frac{1}{3}\left(\mathrm{~b}-\mathrm{a}_{\mathrm{lev}, \mathrm{S}}-\frac{0,5 x_{b}}{\sin \alpha}\right) \cos \alpha+0,5 l_{2}-\eta_{\text {hor, } \mathrm{b}} \cdot l_{2}\right] \text {. } \\
& \cdot \sum R_{s, u p} \cdot \omega_{s, i, u p} \cdot A_{s, i, u p}+ \\
& +\varphi_{7, \mathrm{k}} \cdot\left(\eta_{\mathrm{hor}, \mathrm{b}} \cdot l_{2}-\eta_{\mathrm{s}, \mathrm{s}} \cdot h\right) \cdot \sum R_{s} \cdot \omega_{s, i} \cdot A_{s, i}+ \\
& +\varphi_{7, \mathrm{~d}} \cdot\left[\frac{1}{3}\left(\mathrm{~b}-\mathrm{a}_{\mathrm{lev}, \mathrm{S}}-\frac{0,5 x_{b}}{\sin \alpha}\right) \cos \alpha+0,5 l_{2}+\eta_{\mathrm{hor}, \mathrm{b}} \cdot l_{2}\right] \text {. } \\
& \cdot \sum R_{s, d} \cdot \omega_{s, i, d} \cdot A_{s, i, d}+ \\
& +\left(0,5 h-\mathrm{a}_{s, d}+\eta_{\text {ver }, b} h\right) \cdot \sum R_{s c, u p} \omega_{\text {sc,i,up }} A_{s c, i, u p}- \\
& -\left(0,5 h-\mathrm{a}_{s, u p}-\eta_{v e r, b} h\right) \cdot \sum R_{s c, d} \omega_{\mathrm{sc}, \mathrm{i}, \mathrm{d}} A_{s c, i, d}+ \\
& +\sigma_{\mathrm{s}, \mathrm{sid}, \mathrm{k}} \cdot \mathrm{z}_{\mathrm{i}, \mathrm{up}} \cdot \sum \omega_{\mathrm{s}, \mathrm{i}, \mathrm{sid}} A_{s, i, s i d}- \\
& -\sigma_{\mathrm{s}, \mathrm{sid}, \mathrm{k}} \cdot \mathrm{z}_{\mathrm{i}, \mathrm{d}} \cdot \sum \omega_{\mathrm{s}, \mathrm{i}, \mathrm{sid}} A_{s, i, s i d}+ \\
& +\mathrm{q}_{\mathrm{sw}, \text { lef }} \omega_{\mathrm{sw}, \mathrm{i}, \mathrm{lef}} \cdot f_{2}(\mathrm{c}) \cdot \mathrm{z}_{\mathrm{i}, \mathrm{up}, \mathrm{sw}}- \\
& -\mathrm{q}_{\mathrm{sw}, \text { lef }} \omega_{\mathrm{sw}, \mathrm{i}, \mathrm{lef}} \cdot f_{2}(\mathrm{c}) \cdot \mathrm{z}_{\mathrm{i}, \mathrm{d}, \mathrm{sw}} \\
& -K_{M} \cdot K_{p r, M} \cdot R_{\text {sup }}-R_{\text {sup }} \cdot\left(a_{m, \mathrm{~b}}+\eta_{\text {hor, } \mathrm{b}} \cdot l_{2}\right)=0
\end{aligned}
$$

here $a_{m, \mathrm{~b}}-$ horizontal distance from the support to the center of gravity of the compressed concrete zone in section $k ; \varphi_{5}, \varphi_{6, \mathrm{up}}, \varphi_{6, \mathrm{~d}}, \varphi_{6, k}$, $\varphi_{7, \text { up }} \varphi_{7, \mathrm{~d}},-$ parameters that take into account the components of the "indented" effect in the reinforcement (at each step of the iteration, they are taken into account as constants, not as functions, and are determined based on the secondlevel model); other geometric parameters given in formula (24) are shown in Figures 1, 2; $z_{i \text {,up }}$ - the distance from the side reinforcement, which is located above point $b_{k} ; z_{i, d}$ - the distance from the side reinforcement, which is located below point $b_{k} ; z_{i, u p, s w}-$ the distance from the center of gravity (found through $\left.\omega_{\mathrm{sw}, \mathrm{i}, \mathrm{lef}}\right)$ of the linear force in the clamps located on the side face, above point $\mathrm{b}_{\mathrm{k}} ; \mathrm{z}_{\mathrm{i}, \mathrm{d}, \mathrm{sw}}$ - the distance from the center of gravity (found through $\left.\omega_{\text {sw,i,lef }}\right)$ of the linear force in the clamps located on the side face, below point $b_{k}$. The lateral compressed reinforcement in this equation is not taken into account in view of the smallness of its shoulders relative to the point $\mathrm{b}_{\mathrm{k}}$ (due to the smallness of the parameter $x_{B}$ ); From equation (24) is determined the unknown $\sigma_{s, s i d, k}$ on the left edge.

The sum of the projections of all the forces acting in the spatial section on the $\mathrm{x}$ axis is zero $\left(\sum \mathrm{X}=0\right.$, block II).

$$
\begin{array}{r}
\sum \mathrm{R}_{\mathrm{s}, \mathrm{up}} \cdot \omega_{\mathrm{s,i}, \mathrm{up}} \cdot A_{s, i, u p}+ \\
+\sigma_{\mathrm{s}, \mathrm{sid}, \mathrm{k}} \cdot \sum \omega_{\mathrm{s}, \mathrm{i}, \mathrm{sid}} A_{s, i, s i d} \\
+\sum \mathrm{R}_{\mathrm{s}, \mathrm{d}} \cdot \omega_{\mathrm{s}, \mathrm{i}, \mathrm{d}} \cdot A_{s, i, d}- \\
-\sum R_{s c, u p} \omega_{\mathrm{sc}, \mathrm{i}, \mathrm{up}} A_{s c, i, u p}- \\
-\sum R_{s c, d} \omega_{\mathrm{sc}, \mathrm{i}, \mathrm{d}} A_{s c, i, d}- \\
-\sum \mathrm{R}_{\mathrm{sc}, \mathrm{rig}} \cdot \omega_{\mathrm{sc}, \mathrm{rig}} \cdot A_{\mathrm{sc}, \mathrm{rig}} \\
-\left(\varphi_{10} \cdot \sigma_{b, x, \mathrm{I}} \cdot \varphi_{1}\right) \cdot \omega_{b} \cdot x_{B} \cdot \sqrt{1_{2}^{2}+\mathrm{h}^{2}},
\end{array}
$$

here $\omega_{b}, \varphi_{10}$ are accepted at each iteration in the form of constants.

An unknown $x_{B}$ is found from this equation.

The first case is for the axis of block II $\left(\sum Y=0\right)$, and for the second case it will be the equation $\left(\sum Y=0\right)$.

$$
\begin{gathered}
-q_{s w, \sigma, \mathrm{up}} \cdot \frac{\left(b-a_{u p, s}-x_{b}\right)}{\sin \alpha_{0}} \cdot \omega_{u p}+ \\
+q_{s w, \sigma} \cdot \frac{\left(b-a_{d, s}-x_{b}\right)}{\sin \alpha_{0}} \cdot \omega \\
-\varphi_{8, \mathrm{up}} R_{s} \sum \omega_{u p} A_{s, u p}+ \\
+\varphi_{8, \mathrm{k}, \mathrm{sid}} R_{s, s i d} \sum \omega_{k, s i d} A_{s, s i d} \\
+\varphi_{8, \mathrm{~d}} R_{s} \sum \omega_{d} A_{s, d}=0
\end{gathered}
$$

An unknown $q_{s w, \sigma, \text { up }}$ is found from the equation (26).

The sum of the moments of internal and external forces in the vertical transverse plane rela- 
tive to the $x$ axis passing through the point of application of the resultant forces in the compressed zone is equal to zero $\left(\sum T_{b, k}=0\right.$, block $\left.I I\right)$ :

$$
\begin{aligned}
& -\frac{\tau_{\text {sum }, A} \cdot I_{t, j}}{\sqrt{y^{2}+z^{2}}} \cdot \sin \alpha_{0}-\frac{\tau_{\text {sum }, A} \cdot \psi_{R, T} \cdot I_{t, j}}{\sqrt{y^{2}+z^{2}}} \cdot \sin \alpha_{0}+ \\
& +\varphi_{7, \mathrm{up}} R_{s} \sum \omega_{u p} A_{s, u p} \cdot\left(b-a_{s, u p}-0,5 \cdot x\right)+ \\
& +\varphi_{7, \mathrm{~d}} R_{s} \sum \omega_{d} A_{s, d} \cdot\left(b-a_{s, d}-0,5 \cdot x\right)+ \\
& +\varphi_{7, \mathrm{k}} R_{s} \sum \omega \cdot A_{s} \cdot\left(b-a_{s, l e f}-0,5 \cdot x\right)+ \\
& +\varphi_{8, u p} R_{s} \sum \omega_{u p} A_{s} \cdot\left(0,5 h-\mathrm{a}_{s, u p}-\eta_{v e r, b} h\right)+ \\
& +\varphi_{8, \mathrm{k}} R_{s} \sum \omega \cdot A_{s} \cdot \eta_{\text {ver }, b} h+ \\
& +\varphi_{8, d} R_{s} \sum \omega_{d} A_{s} \cdot\left(0,5 h-\mathrm{a}_{s, u p}+\eta_{v e r, b} h\right)+ \\
& +\mathrm{q}_{\mathrm{sw}, \sigma, \text { up }}\left(0,5 h_{0}-a_{s, u p}-\eta_{\text {ver }, b} h\right)+ \\
& +\mathrm{q}_{\mathrm{sw}, \sigma}\left(0,5 h_{0}-a_{\mathrm{up}, \mathrm{s}}+\eta_{\text {ver }, b} h\right)+ \\
& +\mathrm{q}_{\mathrm{sw}, \text { lef }} \cdot h \cdot \cos \alpha \cdot\left(b-a_{, l e v, s}-0,5 x_{B}\right)- \\
& -\mathrm{K}_{\mathrm{T}} \cdot \mathrm{K}_{\mathrm{pr}, \mathrm{T}} \cdot R_{\text {sup }}-\mathrm{R}_{\text {sup }}\left(0,5 b-0,5 x_{B}\right)=0
\end{aligned}
$$

here $\mathrm{K}_{\mathrm{T}}-\mathrm{a}$ numerical coefficient that takes into account the static loading scheme from the position of additional torques along the length of the rod; $\mathrm{K}_{\mathrm{pr}, \mathrm{T}}$ - coefficient, ratio (it is known, is set) between $R_{\text {sup }}$ and $T$.

Unknown $q_{s w, \sigma}$ is found from the equation (27). The sum of the projections of all the forces acting in the spatial section on the $\mathrm{y}$ axis is zero $\left(\sum Z=0\right.$, block II):

$$
\begin{gathered}
-\mathrm{q}_{\mathrm{sw}, \mathrm{lef}} \cdot h \cdot \cos \alpha-\varphi_{7, d} \mathrm{R}_{\mathrm{s}} \sum \omega_{d} A_{s, d}- \\
-\varphi_{7, u p} R_{\mathrm{s}} \sum \omega_{u p} A_{s, u p}-\varphi_{7, \mathrm{k}} R_{s} \sum \omega \cdot A_{s}+ \\
+\left(\varphi_{10} \cdot \sigma_{b, x, I} \cdot \varphi_{1}\right) \cdot \\
\cdot \omega_{b} \cdot x_{B} \cdot \sqrt{1_{2}^{2}+\mathrm{h}^{2}}+R_{\text {sup }}=0 .
\end{gathered}
$$

Here $\omega_{b}, \varphi_{10}$ are accepted at each iteration in the form of constants. An unknown $\mathrm{q}_{\mathrm{sw} \text {,lef }}$ is found from the equation (28).
Composing a function of many variables with Lagrange multipliers $\lambda_{i}$

$$
\begin{gathered}
F\left(\sigma_{b, x, I}, x, \gamma_{Q, t}, \sigma_{s, I}, \sigma_{s, s i d, k}, x_{B}, q_{s w, \sigma, u p}, q_{s w, \sigma}\right. \\
\left.q_{s w, l e f}, c, \lambda_{1}, \lambda_{2}, \lambda_{3}, \lambda_{4}, \lambda_{5}, \lambda_{6}, \lambda_{7}, \lambda_{8}, \lambda_{9}\right)
\end{gathered}
$$

using equations (1)-(23), and equating the partial derivatives with respect to all variables included in it to zero, we obtain an additional system of equations $[13,15]$ :

$$
\begin{aligned}
& \frac{\partial f}{\partial x_{1}}+\lambda_{1} \frac{\partial \varphi_{1}}{\partial x_{1}}+\lambda_{2} \frac{\partial \varphi_{2}}{\partial x_{1}}+\ldots+\lambda_{m} \frac{\partial \varphi_{m}}{\partial x_{1}}=0 \\
& \frac{\partial f}{\partial x_{2}}+\lambda_{1} \frac{\partial \varphi_{1}}{\partial x_{2}}+\lambda_{2} \frac{\partial \varphi_{2}}{\partial x_{2}}+\ldots+\lambda_{m} \frac{\partial \varphi_{m}}{\partial x_{2}}=0 \\
& \frac{\partial f}{\partial x_{n}}+\lambda_{1} \frac{\partial \varphi_{1}}{\partial x_{n}}+\lambda_{2} \frac{\partial \varphi_{2}}{\partial x_{n}}+\ldots+\lambda_{m} \frac{\partial \varphi_{m}}{\partial x_{n}}=0
\end{aligned}
$$

From the system (29) after the corresponding algebraic transformations, for the two cases considered above, it is possible to obtain the equations for the unknown dangerous spatial crack $c_{\text {inc }}(c)$ on the horizontal:

$$
c_{i n c}(c)=\frac{\sin \alpha(c)+a_{4} \cdot a_{9} \cdot \cos \alpha(c)}{a_{8} \cdot a_{12} \cdot a_{9} \cdot \sin ^{2} \alpha(c)},
$$

The coefficients

$$
a_{4}, a_{8}, a_{9}, a_{12}
$$

included in the equation include almost all the calculation parameters

$$
\begin{gathered}
\sigma_{b, x, I}, x, \gamma_{Q, t}, \sigma_{s, I}, \\
\sigma_{s, s i d, k}, x_{B}, q_{s w, \sigma, u p}, q_{s w, \sigma}, q_{s w, l e f}
\end{gathered}
$$

of the proposed calculation model (Figure 2). 


\section{CONCLUSIONS}

1. The paper proposes a calculation model of the complex resistance of reinforced concrete structures in buildings and structures under the action of torsion with bending. The structure of the model includes a support block (formed by a spatial crack and a compressed concrete zone closed on it, the spatial section $k$ ) and a second block formed by a vertical section $I-I$ extending perpendicular to the longitudinal axis of the reinforced concrete element along the edge of the compressed zone closing the spiral spiral crack .

2. The case is taken into account when, of the three external influences during torsion with bending $(\mathrm{Q}, \mathrm{M}, \mathrm{T})$, the greatest influence on the stress-strain state of structures is exerted by the action of the torque $\mathrm{T}$ (case 2). In the proposed model, when considering the normal section I - I (III - III) and the spatial section $\mathrm{k}$ some parametres are taken into account: the maximum support reaction $R_{\text {sup }}$, the height of the concrete compressed zone in the normal section $x_{B, 1}$, the coefficient for determining the shear force $\gamma_{Q, t}$, the longitudinal reinforcement stress in the normal section $\sigma_{s, I}$, the side reinforcement stress in the spatial section $\sigma_{s, s i d, k}$, the height of the compressed zone of the spatial section $x_{B, k}$, the linear force in the transverse reinforcement located at the lateral, upper and lower faces $q_{s w, \sigma, u p}, q_{s w, \sigma}, q_{s w, l e f}$, normal stresses in concrete $\sigma_{b u, x, \mathrm{I}}$, component axial stresses in the working reinforcement intersected by a spatial crack $\sigma_{\mathrm{s}, \mathrm{up}}, \sigma_{\mathrm{sc}, \mathrm{up}}, \sigma_{\mathrm{s}, \mathrm{d}}, \sigma_{\mathrm{sc}, \mathrm{d}}$, tangential forces in concrete $\omega_{1} \tau_{y z}, \omega_{2} \tau_{z}$; components of the loading effort in the working reinforcement intersected by a spatial crack $k$, as well as the lengths of the projections of the parts of the spatial crack on the horizontal axis $l_{1}, l_{2}, l_{3}\left(c_{i}\right)$.

3. When assessing the resistance of reinforced concrete structures of rectangular and complex cross sections (consisting of a set of rectangles), the authors use the technique, which is based on the fact that the rectangular section is divided into a series of squares, which are subsequently replaced by the circles inscribed in them.

4. The resolving equations for the proposed model are compiled, forming a closed system and the Lagrange function combining them is written. Using partial derivatives of the constructed function with respect to all variables included in it and equating them to zero, an additional system of equations is compiled, from which, after the corresponding algebraic transformations, a dependence is obtained that allows one to find the projection of a dangerous spatial crack.

\section{REFERENCES}

1. Golyshev A.B., Kolchunov V.I. Soprotivleniye zhelezobetona [The resistance of reinforced concrete]. Kiev, Basis, 2009, 432 pages (in Russian).

2. Bondarenko V.M., Kolchunov V.I. Raschetnye modeli silovogo soprotivleniya zhelezobetona [The computational model of a power resistance of reinforced concrete]. Moscow, ASV, 2004, 472 pages (in Russian).

3. Vishnu H. Jariwalaa, Paresh V. Patel, Sharadkumar P. Purohit. Strengthening of RC Beams subjected to Combined Torsion and Bending with GFRP Composites. // Procedia Engineering, 2013, Volume 51, pp. 282-289.

4. Adheena T., Afia S.H. An Experimental Study On Combined Flexural And Torsional Behaviour Of RC Beams. // International Research Journal of Engineering and Technology, 2017, Volume 04, Issue 05, pp. 1367-1370. 
5. Rahal K. Combined Torsion and Bending in Reinforced and Prestressed Concrete beams Using Simplified Method for Combined Stress-Resultants. // ACI Structural Journal, 2007, Volume 104, No. 4, pp. 402411.

6. Kolchunov Vl.I., Salnikov A.S. Eksperimentalnyye issledovaniya treshchinoobrazovaniya zhelezobetonnyye konstruktsiy pri kruchenii s izgibom [Experimental studies of crack formation of reinforced concrete structures under action torsion with bending]. // Building and Reconstruction, 2016, No. 65(3), pp. 24-32 (in Russian).

7. Demyanov A.I., Salnikov A.S., Kolchunov Vl.I. Eksperimentalnye issledovaniya zhelezobetonnykh konstruktsiy pri kruchenii s izgibom i analiz ikh rezultatov [The experimental investigations of reinforced concrete constructions under the action torsion with bending and analysis of their results]. // Building and Reconstruction, 2017, No. 72(4), pp. 17-26 (in Russian).

8. Demyanov A.I., Pokusaev A.A., Kolchunov V.I. Eksperimentalnye issledovaniya deformirovaniya zhelezobetonnykh konstruktsiy pri kruchenii s izgibom [The experimental investigations of deformation reinforced concrete structures under the action torsion with bending]. // Building and Reconstruction, 2017, No. 73(5), pp. 5-14 (in Russian).

9. Demyanov A.I., Kolchunov V.I., Pokusaev A.A. Eksperimentalnye issledovaniya deformirovaniya zhelezobetonnykh konstruktsiy pri kruchenii s izgibom [The experimental investigations of deformation reinforced concrete structures under the action torsion with bending]. // Structural Mechanics of Engineering Constructions and Buildings, 2017, No. 6, pp. 37-44 (in Russian).

10. Santhakumar R., Dhanaraj R., Chandrasekaran E. Behaviour of retrofitted reinforced concrete beams under combined bending and torsion: A numerical study. //
Electronic Journal of Structural Engineering, 2007, No. 7, pp. 1-7.

11. Kalkan I., Kartal S. Torsional Rigidities of Reinforced Concrete Beams Subjected to Elastic Lateral Torsional Buckling. // International Journal of Civil and Environmental Engineering, 2017, Volume 11, No. 7, pp. 969-972.

12. Salnikov A., Kolchunov Vl., Yakovenko I. The computational model of spatial formation of cracks in reinforced concrete constructions in torsion with bending. // Applied Mechanics and Materials, 2015, Vols. 725-726, pp. 784-789.

13. Iakovenko I., Kolchunov Vl. The development of fracture mechanics hypotheses applicable to the calculation of reinforced concrete structures for the second group of limit states. // Journal of Applied Engineering Science, 2017, Volume 15, pp. 366-375.

14. Demyanov A. I., Kolchunov Vl.I., Yakovenko I.A. Razrabotka universalnogo korotkogo dvukhkonsolnogo elementa $\mathrm{k}$ soprotivleniyu zhelezobetonnykh konstruktsiy pri kruchenii s izgibom [The development of universal short doublecantilever element, for resistance of reinforced concrete structures under the action torsion with bending]. // The News of Higher Educational Institutions Technology of Textile Industry, 2017, No. 367(4), pp. 258263 (in Russian).

15. Iakovenko I., Kolchunov V., Lymar I. Rigidity of reinforced concrete structures in the presence of different cracks. // MATEC Web of Conferences. 6th International Scientific Conference "Reliability and Durability of Railway Transport Engineering Structures and Buildings". Transbud-2017, Kharkiv, Ukraine, April 19-21, 2017, Volume 0216, 12 pages.

16. Pettersen J.S. Non-Linear Finite Element Analyses of Reinforced Concrete with Large Scale Elements: Including a Case Study of a Structural Wall. Norwegian University of Science and Technology, 2014, 85 pages. 
17. Nahvi H., Jabbari M. Crack detection in beams using experimental modal data and finite element model. // International Journal of Mechanical Sciences, 2005, Volume 47, pp. 1477-1497.

18. Al-Bayati, G., Al-Mahaidi, R., Kalfat, R. Torsional strengthening of reinforced concrete beams using different configurations of NSM FRP with epoxy resins and cement-based adhesives. // Composite Structures, 2016, Volume 168, pp. 569-581.

19. Golyshev A.B., Bachinskiy V.Ya., Polishchuk V.P., Kharchenko A.V., Rudenko I.V. Proyektirovaniye zhelezobetonnykh konstruktsiy: Spravochnoye posobiye [Design of reinforced concrete structures: a reference guide]. Kiev, Budivelnyk, 1990, 544 pages.

20. Shen, K., Wan, S., Mo, Y.L., Jiang, Z. Theoretical analysis on full torsional behavior of RC beams strengthened with FRP materials. // Composite Structures, 2016, No 1(183), pp. 347-357.

21. Huang, L., Yan, B., Yan, L., Xu, Q., Tan, H., Kasal, B. Reinforced concrete beams strengthened with externally bonded natural flax FRP plates. // Composites Part B: Engineering, 2016, Volume 91, pp. 569-578.

22. Gunasekaran, K., Ramasubramani, R., Annadurai, R., Prakash Chandar, S. Study on reinforced lightweight coconut shell concrete beam behavior under torsion. // Materials and Design, 2014, Vol. 57, pp. 374-382.

23. Awadh E.A. Torsion plus bending and shear on reinforced concrete beams. // Journal of Engineering and Sustainable Development, 2016, No. 4, pp. 277-288.

\section{СПИСОК ЛИТЕРАТУРЫ}

1. Голышев А.Б., Колчунов В.И. Сопротивление железобетона. - Киев: Основа, 2009. - 432 c.
2. Бондаренко В.М., Колчунов В.И. Расчетные модели силового сопротивления железобетона. - М.: АСВ, 2004. - 472 с.

3. Vishnu H. Jariwalaa, Paresh V. Patel, Sharadkumar P. Purohit. Strengthening of RC Beams subjected to Combined Torsion and Bending with GFRP Composites. // Procedia Engineering, 2013, Volume 51, pp. 282-289.

4. Adheena T., Afia S.H. An Experimental Study On Combined Flexural And Torsional Behaviour Of RC Beams. // International Research Journal of Engineering and Technology, 2017, Volume 04, Issue 05, pp. 1367-1370.

5. Rahal K. Combined Torsion and Bending in Reinforced and Prestressed Concrete beams Using Simplified Method for Combined Stress-Resultants. // ACI Structural Journal, 2007, Volume 104, No. 4, pp. 402411.

6. Колчунов В.И., Сальников А.С. Экспериментальные исследования трещинообразования железобетонные конструкций при кручении с изгибом. // Cmpouтельство и реконструкичи,, 2016, №3(65), c. 24-32.

7. Демьянов А.И., Сальников А.С., Колчунов Вл.И. Экспериментальные исследования железобетонных конструкций при кручении с изгибом и анализ их результатов. // Строительство и реконструкичия, 2017, №4(72), с. 17-26.

8. Демьянов А.И., Покусаев А.А., Колчунов В.И. Экспериментальные исследования железобетонных конструкций при кручении с изгибом. // Cтроительство и реконструкиия, 2017, №5(73), с. 5-14.

9. Демьянов А.И., Колчунов В.И., Покусаев А.А. Экспериментальные исследования деформирования железобетонных конструкций при кручении с изгибом. // Строительная механика инженерных конструкций и сооружений, 2017, №6, с. 37-44. 
10. Santhakumar R., Dhanaraj R., Chandrasekaran E. Behaviour of retrofitted reinforced concrete beams under combined bending and torsion: A numerical study. // Electronic Journal of Structural Engineering, 2007, No. 7, pp. 1-7.

11. Kalkan I., Kartal S. Torsional Rigidities of Reinforced Concrete Beams Subjected to Elastic Lateral Torsional Buckling. // International Journal of Civil and Environmental Engineering, 2017, Volume 11, No. 7, pp. 969-972.

12. Salnikov A., Kolchunov Vl., Yakovenko I. The computational model of spatial formation of cracks in reinforced concrete constructions in torsion with bending. // Applied Mechanics and Materials, 2015, Vols. 725-726, pp. 784-789.

13. Iakovenko I., Kolchunov Vl. The development of fracture mechanics hypotheses applicable to the calculation of reinforced concrete structures for the second group of limit states. // Journal of Applied Engineering Science, 2017, Volume 15, pp. 366-375.

14. Демьянов А.И., Колчунов Вл.И., Яковенко И.А Разработка универсального короткого двухконсольного элемента к сопротивлению железобетонных конструкций при кручении с изгибом. // Известия ВУЗов. Технология текстильной промышленности, 2017, №4(367), с. 258263.

15. Iakovenko I., Kolchunov V., Lymar I. Rigidity of reinforced concrete structures in the presence of different cracks. // MATEC Web of Conferences. 6th International Scientific Conference "Reliability and Durability of Railway Transport Engineering Structures and Buildings". Transbud-2017, Kharkiv, Ukraine, April 19-21, 2017, Volume 0216, 12 pages.

16. Pettersen J.S. Non-Linear Finite Element Analyses of Reinforced Concrete with Large Scale Elements: Including a Case Study of a Structural Wall. Norwegian University of Science and Technology, 2014, 85 pages.
17. Nahvi H., Jabbari M. Crack detection in beams using experimental modal data and finite element model. // International Journal of Mechanical Sciences, 2005, Volume 47, pp. 1477-1497.

18. Al-Bayati, G., Al-Mahaidi, R., Kalfat, R. Torsional strengthening of reinforced concrete beams using different configurations of NSM FRP with epoxy resins and cement-based adhesives. // Composite Structures, 2016, Volume 168, pp. 569-581.

19. Голышев А.Б., Бачинский В.Я., Полищук В.П. Проектирование железобетонных конструкций. - Киев: Будивельник, 1990. - 544 с.

20. Shen K., Wan S., Mo Y.L., Jiang Z. Theoretical analysis on full torsional behavior of RC beams strengthened with FRP materials. // Composite Structures, 2016, No. 1(183), pp. 347-357.

21. Huang, L., Yan, B., Yan, L., Xu, Q., Tan, H., Kasal, B. Reinforced concrete beams strengthened with externally bonded natural flax FRP plates. // Composites Part B: Engineering, 2016, Volume 91, pp. 569-578.

22. Gunasekaran, K., Ramasubramani, R., Annadurai, R., Prakash Chandar, S. Study on reinforced lightweight coconut shell concrete beam behavior under torsion. // Materials and Design, 2014, Vol. 57, pp. 374-382.

23. Awadh E.A. Torsion plus bending and shear on reinforced concrete beams. // Journal of Engineering and Sustainable Development, 2016, No. 4, pp. 277-288.

Vladimir I. Kolchunov, Dr.Sc., Professor, Department of unique building and structures, South-Western State University, 94, 50 let Oktyabrya street, Kursk, 305040,Russia phone: +7 (910) 317-93-55; e-mail: vlik52@mail.ru.

Aleksey I. Demyanov, Candidate of Technical Sciences, Associated Professor, Department of unique building and structures, South-Western State University, 94, 50 let Oktyabrya street, Kursk, 305040, Russia;

E-mail: speccompany@gmail.com. 
Nikolay V. Naumov, PhD student of Department of unique building and structures, South-Western State University, 94, 50 let Oktyabrya street, Kursk, 305040, Russia;

E-mail: speccompany@gmail.com.

Колчунов Владимир Иванович, доктор технических наук, профессор кафедры «Уникальные здания и сооружения», Юго-Западный государственный университет; 305040, Россия, г. Курск, ул. 50 лет Октября, дом 94; тел.: +7 (910) 317-93-55; e-mail: vlik52@mail.ru.

Демьянов Алексей Иванович, кандидат технических наук, доцент кафедры «Уникальные здания и сооружения», Юго-Западный государственный университет; 305040, Россия, г. Курск, ул. 50 лет Октября, дом 94; e-mail: speccompany@gmail.com

Наумов Николай Валерьевич, аспирант кафедры «Уникальные здания и сооружения», Юго-Западный государственный университет; 305040, Россия, г. Курск, ул. 50 лет Октября, дом 94;

E-mail: kolua199200@yandex.ru 